\title{
The Social Map as a participative instrument to elaborate the Integrated Fire Management Plan of the Chapada dos Guimarães National Park
}

\author{
Flavia Lopes Bertier', Regina A. Silva ${ }^{2}$, Giseli Dalla-Nora ${ }^{3}$, Luiz Gustavo Gonçalves ${ }^{4}$
}

\footnotetext{
${ }^{1}$ Education Institute, Mato Grosso Federal University (IE-UFMT), Chico Mendes Institute for Biodiversity Conservation (ICMBio), Chapada dos Guimarães/MT, Brazil - pncgflavia@gmail.com

${ }^{2}$ Education Institute, Mato Grosso Federal University (IE-UFMT), Cuiabá/MT, Brazil - rasbio@ gmail.com

${ }^{3}$ Geography, History and Documantation Institute, Mato Grosso Federal University (IGHD-UFMT), Cuiabá/MT, Brazil - giseli.nora@gmail.com

${ }^{4}$ Chico Mendes Institute for Biodiversity Conservation (ICMBio), Chapada dos Guimarães/MT, Brazil luiz.goncalves@icmbio.gov.br
}

\begin{abstract}
Promoting the participation of surrounding communities and valuing their knowledge and cultural manifestations are objectives included in the Chapada dos Guimarães National Park Management Plan, wich extends to the fire management. This study presents how the "Social Map of popular knowledge related to fire" held in the São Jerônimo community contributed to the elaboration of the park's Integrated Fire Management Plan - PMIF 2019. Social mapping activities has followed the 'path' of fire in the daily life of the community since ancient times. The community has been experiencing recurrent wildfires in recent years due to water scarcity and local geographic formation, which turns fire combat more difficult. A mapping meeting and interviews with older residents allowed to identify spatially how their inhabitants dealt and deal with fire (habits), and how it interferes with their well-being and in nature (habitat). From the cartographies elaborated with and by the residents, it is possible to visualize fire as a fundamental dualogical social being in the daily life of the community. The bureaucracy to get controlled burning permits and the frequent incidence of wildfires, among other factors, contribute to the outbreak of social and environmental conflicts. By incorporating traditional knowledge into PMIF, we give audience and add value to the local culture. The stimulus to a dialogue based on the generating theme "fire" is the basis for a practical and reflective environmental education, settled in making and acting experiences, under the axiomatic perspective of values, ethics and political vision inherent in environmental education. Now, the park's management team is waiting for adequate climate conditions to implement prescribed fires in the Morro São Jerônimo region implementing the community suggestions listed in the Social Map. This process reflects an Ecology of Knowledge, which it is expected to build instruments that may contribute not only to environmental conservation and the reduction of incidence of wildfires in the region, but also to strengthen the community and identify possible public policies that reflect realities lived by the residents of São Jerônimo and the other communities around the Chapada dos Guimarães National Park.
\end{abstract}

Keywords: Social Map, environmental education, fire integrated management, participative environmental management 